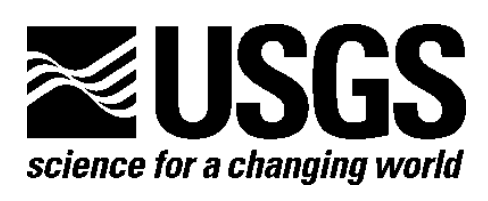

\title{
Logs and Data from Trenches Across and Near the Green Valley Fault at the Mason Road Site, Fairfield, Solano County, California, 2006-2009
}

By James J. Lienkaemper, Robert R. Sickler, Shannon A. Mahan, Johnathan Brown, Liam M. Reidy, and Mindy A. Kimball

Pamphlet to accompany

Open-File Report 2012-1011

U.S. Department of the Interior

U.S. Geological Survey 


\section{U.S. Department of the Interior \\ KEN SALAZAR, Secretary}

U.S. Geological Survey
Marcia K. McNutt, Director

U.S. Geological Survey, Reston, Virginia: 2012

For product and ordering information:

World Wide Web: http://www.usgs.gov/pubprod

Telephone: 1-888-ASK-USGS

For more information on the USGS-the Federal source for science about the Earth, its natural and living resources, natural hazards, and the environment:

World Wide Web: http://www.usgs.gov

Telephone: 1-888-ASK-USGS

Suggested citation:

Lienkaemper, J.J., Sickler, R.R., Mahan, S.A., Brown, Johnathan, Reidy, L.M., and Kimball, M.A., 2012, Logs and data from trenches across and near the Green Valley Fault at the Mason Road site, Fairfield, Solano County,

California, 2006-2009: U.S. Geological Survey Open-File Report 2012-1011, pamphlet 5 p., 5 sheets. (Available at http://pubs.usgs.gov/of/2012/1011/.)

Any use of trade, product, or firm names is for descriptive purposes only and does not imply endorsement by the U.S. Government.

Although this report is in the public domain, permission must be secured from the individual copyright owners to reproduce any copyrighted material contained within this report. 


\section{Contents}

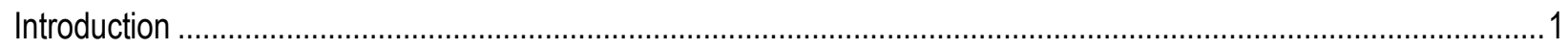

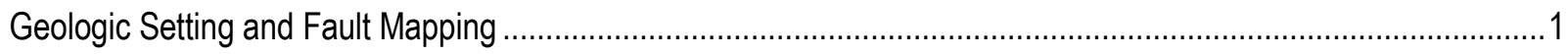

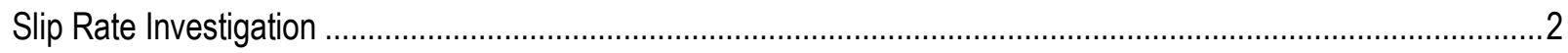

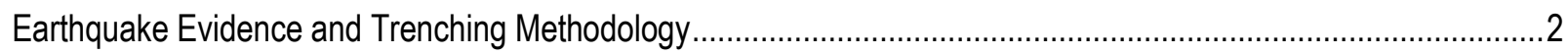

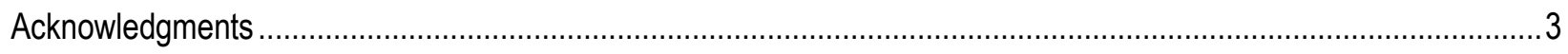

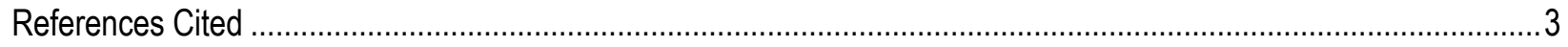

\section{Tables}

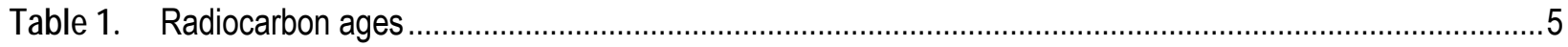




\section{Logs and Data from Trenches Across and Near the Green Valley Fault at the Mason Road Site, Fairfield, Solano County, California, 2006-2009}

By James J. Lienkaemper, ${ }^{1}$ Robert R. Sickler, ${ }^{1}$ Shannon A. Mahan, ${ }^{1}$ Johnathan Brown, ${ }^{1}$ Liam M. Reidy, ${ }^{2}$ and Mindy A. Kimball ${ }^{3}$

\section{Introduction}

The primary purpose of this report is to provide drafted field logs of exploratory trenches excavated across the Green Valley Fault in 2007 and 2009 that show evidence for four surface-rupturing earthquakes in the past one thousand years. The site location and site detail are shown on sheet 1 (figs. 1 and 2). The trench logs are shown on sheets 1, 2, and 3. We also provide radiocarbon laboratory dates (table 1) used for chronological modeling of the earthquake history. Sheets 4 and 5 show additional data obtained in 20062009 to document data obtained in our studies of the long-term geologic slip rate on the Green Valley Fault. However, that effort ultimately did not prove feasible and no slip rate estimate resulted.

\section{Geologic Setting and Fault Mapping}

The Green Valley Fault location is identified north and south of the trench site by aerial photo interpretation of its geomorphic expression (Wallace, 1990) and from en echelon cracks caused by fault creep in the asphalt-concrete pavement of Mason Road (sheet 1, fig. 2). The trench site is located in distal alluvial fan deposits that have been offset by right-lateral slip on the fault, which has formed a low scarp and subtle closed depression near trench 07S (fig. 2; below the resolution of the contouring, but fills seasonally with rainwater). Although expression of faulting in trench 07S was almost entirely obscured by highly bioturbated marshy soil deposits, the fault is well resolved at depth by highresolution seismic imaging (Kimball and others, 2011). Because faulting in trench 07S was in evidence only as a monoclinal warp (in north and south walls) yielding no evidence of individual earthquake ruptures, we logged only the south wall (sheet 3). In contrast, the fault was expressed clearly in trenches N1-N3 (sheet 1, fig. 1 inset; sheet 2) located about

1 U.S. Geological Survey

2 University of California, Berkeley

3 California State University East Bay, Hayward 
$100 \mathrm{~m}$ to the north of trench $07 \mathrm{~S}$. Because there is no surface expression of the fault at this site, even in historical aerial photographs, we chose where to trench based on a distinct step in the water table across a distance of only a few meters as observed in cone penetration testing (Bennett and others, 2011) and supplemented by more closely spaced hand augering.

\section{Slip Rate Investigation}

The Mason Road site was initially selected because 1896 topographic maps showed a large (400-600-m) right-lateral offset of a minor stream, Hennessey Creek, suggesting that if this offset could be dated then we might obtain a long-term slip rate. The slip rate of the Green Valley Fault has nowhere been determined by local evidence, rather the slip rate has been inferred to be $5 \pm 3 \mathrm{~mm} / \mathrm{yr}$ based on regional assumptions about continuity of observed rates on connected faults to the north and south of the Green Valley Fault (Working Group on California Earthquake Probabilities, 2003, 2008). To determine slip rate, we needed to identify and to date stream sediments associated with initiation of the inferred offset. These sediments were expected to be approximately 100 thousand years old, too old for radiocarbon dating but within the range for optically stimulated luminescence (OSL) dating. During 2006 through 2009, we used cone penetration tests (CPT) and soil borings to characterize the material types and ages within the fan deposits near the fault and the geometry of the subsurface stream channel (for test results see Bennett and others, 2011). Initial results suggested an older stream channel might have been within reach by excavation and so, in 2006, we excavated a pit. This Mason Road Pit 2006 map, logs, and dating results are shown on sheet 4 . The OSL dates correspond fairly closely to radiocarbon dates (sheet 4 , table 1 ). The pit was not deep enough to measure the long-term offset that we sought, therefore we used a boring to probe for possible evidence of channel initiation inferred from interpretation of the CPT profile to be at a depth of $12 \mathrm{~m}$ (location SNC07 in sheet 1, fig. 2; details of Core SNC07 in sheet 5, and in Bennett and others, 2011). However, the materials at this 12 -m depth were not sufficiently old (only about 12,000 years old) to correlate with the large amount of offset inferred from the 1896 map. We also attempted to image buried channel geometry using ground-penetrating radar (Craig and others, 2011), but the results could not adequately resolve channel structures much deeper than about 5-10 m. Kimball and others (2011) used high-resolution seismic refraction techniques that clearly imaged the fault at greater depths, thus suggesting the possibility that we might also be able to identify stream channels at greater depths.

Encouragingly, in 2007, surveys east of the fault did indicate a channel at 10-15 m depths, however, in 2009, surveys west of the fault found no matching channel (Craig, 2010). An additional boring at "stake 11" location (sheet 1, fig. 2) was done but we did no additional dating of this buried channel because we had not found any matching offset stream channel deposits west of the fault.

\section{Earthquake Evidence and Trenching Methodology}

In 2007, we excavated two cross-fault trenches and three more in 2009 at the site, seeking evidence for paleoearthquakes (sheets 1 and 2) as has been described on another creeping fault in the region, the Hayward Fault (Lienkaemper and others, 2002a, 2010). We identified evidence for a sequence of four ground-rupturing events in the past millennium 
(Lienkaemper and others, unpub. data). Earlier ruptures could not be clearly distinguished or dated. The long-axes of trenches N1, N2, and N3 orient perpendicular to the fault; trench N4 is parallel to the fault (fig. 2). Trench N4 was used to show continuity of stratigraphic units. The general stratigraphy is composed of a series of alluvial deposits overlying a marshy, bioturbated silty clay unit (u10). The alluvial deposits are characterized by variation between more silty and sandy units (u20, u40, u60, u80, u100) and more clayey organic units having varying degrees of soil development (u30, u50, u70, u90). The methodology used in logging the trenches is described in Lienkaemper and others (2002b). Logging was done on high-resolution, ortho-rectified photo mosaics of the trench walls. Raw radiocarbon ages are shown in table 1 below. Nine pollen samples were taken from trench $\mathrm{N} 1$ (m 0.7 in units u80, u90, and u100); however, pollen preservation was poor. The species of non-native pollen, Erodium cicutarium, indicative of the earliest historical period (about 1770-1780), was not observed in any of these samples, but the sandy material provided such an oxidative environment that the results are not conclusive.

\section{Acknowledgments}

This investigation was funded by the U.S. Geological Survey National Earthquake Hazard Reduction Program. We owe many thanks to the late Billy Yarbrough and his family, especially Debra and Anthony Russo, without whose continuing practical assistance, this work would not have been possible. Reviews by Suzanne Hecker and Dan Ponti and text edit by Theresa Iki greatly improved this report.

\section{References Cited}

Bennett, M.J., Noce, T.E., and Lienkaemper, J.J., 2011, Cone penetration tests and soil borings at Mason Road, Green Valley, Solano County, California: U.S. Geological Survey OpenFile Report 2011-1281, 52 p.

Craig, M.S., Kimball, Mindy, and Lienkaemper, J.J., 2011, Ground penetrating radar surveying of the Green Valley Fault, San Francisco Bay Area, CA, in Knudsen, K., Baldwin, J., Brocher, T., Bürgmann, R., Craig, M., Cushing, D., Hellweg, P., Wiegers, M., and Wong, I., eds., Proceedings of the 3rd Conference on earthquake hazards in the eastern San Francisco Bay area: California Geological Survey Special Report 219, p. 381-390.

Craig, M.S., 2010, Near-surface geophysical imaging of paleochannels for the determination of slip rate at the Green Valley Fault, U.S. Geological Survey, National Earthquake Hazard Reduction Program, Final Technical Report for Award Number G09AP00077, 19 p., accessed February 22, 2011, at http://earthquake.usgs.gov/research/external/reports/G09AP00077.pdf

Kimball, M.A., 2005, Seismic refraction on the Green Valley and Hayward Faults, San Francisco Bay Area, CA: California State University, East Bay, Masters Thesis. 
Kimball, Mindy, Craig, M.S., and Lienkaemper, J.J., 2011, Using seismic refraction to identify and characterize near-surface expression of active faults in the eastern San Francisco Bay Area, CA, in Knudsen, K., Baldwin, J., Brocher, T., Bürgmann, R., Craig, M., Cushing, D., Hellweg, P., Wiegers, M., and Wong, I., eds., Proceedings of the 3rd Conference on earthquake hazards in the eastern San Francisco Bay area: California Geological Survey Special Report 219, p. 369-380.

Lienkaemper, J., Dawson, T., Personius, S., Seitz, G., Reidy, L., and Schwartz, D., 2002a, A record of large earthquakes on the southern Hayward fault for the past 500 years: Bulletin of the Seismological Society of America, v. 92, no. 7, p. 2637-2658.

Lienkaemper, J., Dawson, T., Personius, S., Seitz, G., Reidy, L., and Schwartz, D., 2002b, Logs and data from trenches across the Hayward Fault at Tyson's Lagoon (Tule Pond), Fremont, Alameda County, California: U.S. Geological Survey Miscellaneous Field Studies Map MF-2386, 12 p., 2 plates, accessed February 22, 2011, at http://pubs.usgs.gov/mf/2002/2386/.

Lienkaemper, J.J., Williams, P.L., and Guilderson, T.P., 2010, Evidence for a 12th large earthquake on the southern Hayward fault in the past 1900 years: Bulletin of the Seismological Society of America, v. 100, no. 5A, p. 2024-2034.

McFarland, F.S., Lienkaemper, J. J., and Caskey, S.J., 2009, Data from theodolite measurements of creep rates on San Francisco Bay region faults, California, 19792009: U.S. Geological Survey Open-File Report 2009-1119, version 1.2 (2011), p. 17, accessed April 5, 2012, at http://pubs.usgs.gov/of/2009/1119/.

Prescott, J.R., and Hutton, J.T., 1994, Cosmic ray contribution to dose rates for luminescence and ESR dating; large depths and long-term time variations: Radiation Measurements, v. 23, p. 497-500.

Stuiver, M., and Polach, H., 1977, Discussion; reporting of 14C data: Radiocarbon, v.19, p. 355-363.

U.S. Geological Survey and California Geological Survey, 2006, Quaternary fault and fold database for the United States: U.S. Geological Survey and California Geological Survey, accessed February 22, 2011, at http://earthquake.usgs.gov/regional/qfaults/.

Wallace, R.E., 1990, Geomorphic expression, in Wallace, R.E., ed., The San Andreas Fault System, California: U.S. Geological Survey Professional Paper 1515, p. 14-58.

Working Group on California Earthquake Probabilities, 2003, Earthquake probabilities in the San Francisco Bay Region; 2002-2031: U.S. Geological Survey Open-File Report 2003-214, accessed February 22, 2011, at http://pubs.usgs.gov/of/2003/of03-214/.

Working Group on California Earthquake Probabilities, 2008, The uniform California earthquake rupture forecast, version 2 (UCERF 2): U.S. Geological Survey Open-File Report 2007-1437, February 22, 2011, at http://pubs.usgs.gov/of/2007/1437/. 
Table 1. Radiocarbon ages.

\begin{tabular}{|c|c|c|c|c|c|c|c|c|c|}
\hline $\begin{array}{c}\text { Sample } \\
\text { no. }{ }^{1}\end{array}$ & Material & $\begin{array}{c}{ }^{14} \mathrm{C} \text { age (yr) } \\
\mathrm{BP}^{2}\end{array}$ & Unit no. (u\#) & $\begin{array}{l}\text { Expos. } \\
- \text { Wall }^{3}\end{array}$ & $\begin{array}{l}\text { Location } \\
\text { (m) }\end{array}$ & $\partial^{13} C^{4}$ & Fraction modern & $\partial^{14} \mathbf{C}$ & Lab. no. ${ }^{5}$ \\
\hline $07 \mathrm{~N} 24$ & charcoal & $670 \pm 30$ & u100 & N1-n & 7 & -26.1 & $0.9198 \pm 0.0031$ & -80.2 & 135766 \\
\hline $07 \mathrm{~N} 13$ & charcoal & $480 \pm 35$ & u80 & N1-n & 4 & -25 & $0.9422 \pm 0.0036$ & -57.8 & 137742 \\
\hline $07 \mathrm{~N} 14 *$ & charcoal & $530 \pm 30$ & u80 & N1-n & 4 & -24.8 & $0.9360 \pm 0.0031$ & -64.0 & 135763 \\
\hline 07N03 & charcoal & $1700 \pm 60$ & u80 & N1-n & 0 & -25 & $0.8088 \pm 0.0053$ & -191.2 & 137741 \\
\hline 07N01 & charcoal & $2480 \pm 270$ & u80 & N1-n & 0 & -25 & $0.7342 \pm 0.0246$ & -265.8 & 137740 \\
\hline $07 \mathrm{~N} 26$ & charcoal & $800 \pm 30$ & $\mathrm{u} 70$ & N1-s & 9 & -25 & $0.9054 \pm 0.0032$ & -94.6 & 135767 \\
\hline 07N20 & charcoal & $815 \pm 35$ & $\mathrm{u} 70$ & N1-n & 6 & -25 & $0.9037 \pm 0.0036$ & -96.3 & 135765 \\
\hline $07 \mathrm{~N} 29$ & charcoal & $845 \pm 35$ & u70 & N1-n & 9 & -25 & $0.9002 \pm 0.0036$ & -99.8 & 135768 \\
\hline 07N15a* & charcoal & $865 \pm 30$ & u60 & N1-n & 4 & -24.4 & $0.8982 \pm 0.0030$ & -101.8 & 135764 \\
\hline 07N15b & charcoal & $880 \pm 30$ & u60 & N1-n & 4 & -24 & $0.8961 \pm 0.0030$ & -103.9 & 135998 \\
\hline N3-2a & charcoal & $745 \pm 30$ & u50 & N3-n & 5 & -25 & $0.9116 \pm 0.0033$ & -88.4 & 145907 \\
\hline $\mathrm{N} 3-2 \mathrm{~b}$ & charcoal & $865 \pm 40$ & u50 & N3-n & 5 & -25 & $0.8978 \pm 0.0041$ & -102.2 & 145912 \\
\hline N3-4 & charcoal & $1060 \pm 30$ & u50 & N3-n & 7 & -25 & $0.8766 \pm 0.0032$ & -123.4 & 145908 \\
\hline 07N08b & charcoal & $900 \pm 35$ & $\mathrm{u} 40$ & N1-s & 1 & -25 & $0.8941 \pm 0.0035$ & -105.9 & 135770 \\
\hline 07N08a* & charcoal & $950 \pm 30$ & $\mathrm{u} 40$ & N1-s & 1 & -24.6 & $0.8885 \pm 0.0030$ & -111.5 & 135761 \\
\hline 07N10* & charcoal & $1005 \pm 30$ & $\mathrm{u} 40$ & N1-n & 2 & -25.6 & $0.8826 \pm 0.0028$ & -117.4 & 135762 \\
\hline N3-1a & charcoal & $950 \pm 35$ & fissure in u30 & N3-n & 5 & -25 & $0.8885 \pm 0.0035$ & -111.5 & 145906 \\
\hline $\mathrm{N} 3-1 \mathrm{~b}$ & charcoal & $970 \pm 35$ & fissure in u30 & N3-n & 5 & -25 & $0.8865 \pm 0.0035$ & -113.5 & 145911 \\
\hline $\mathrm{N} 2-2$ & bulk & $640 \pm 180$ & u30 & N2-n & 6 & -25 & $0.9230 \pm 0.0197$ & -77.0 & 145914 \\
\hline N3-5 & charcoal & $1290 \pm 35$ & u30 & N3-n & 10 & -25 & $0.8515 \pm 0.0035$ & -148.5 & 145909 \\
\hline N2-1 & charcoal & $1015 \pm 35$ & u30 & N2-n & 6 & -25 & $0.8813 \pm 0.0036$ & -118.7 & 145910 \\
\hline 07N31* & bulk & $1810 \pm 30$ & u10 & N1-s & 2 & -25.8 & $0.7984 \pm 0.0027$ & -201.6 & 135769 \\
\hline MR07-06a & charcoal & $10,905 \pm 35$ & - & SNC7 & - & -25 & $0.2574 \pm 0.0011$ & -742.6 & 137744 \\
\hline MR07-06b & charcoal & $10,970 \pm 35$ & - & SNC7 & - & -25 & $0.2553 \pm 0.0011$ & -744.7 & 135772 \\
\hline MR07-09a & twig & $10,950 \pm 35$ & - & SNC7 & - & -25 & $0.2558 \pm 0.0011$ & -744.2 & 135773 \\
\hline MR07-09b & bulk & $14,015 \pm 45$ & - & SNC7 & - & -25 & $0.1747 \pm 0.0009$ & -825.3 & 135771 \\
\hline MRP-4 & charcoal & $840 \pm 35$ & pit-35 & 06Pit & - & -25 & $0.9005 \pm 0.0036$ & -99.5 & 129414 \\
\hline MRP-7 & charcoal & $950 \pm 30$ & pit-45 & 06Pit & - & -27.0 & $0.8887 \pm 0.0029$ & -111.3 & 129415 \\
\hline MRP-3 & charcoal & $3085 \pm 30$ & pit-70 & 06Pit & - & -26.6 & $0.6813 \pm 0.0022$ & -318.7 & 129413 \\
\hline MRP-8 & bulk & $6335 \pm 45$ & pit-80 & 06Pit & - & -25 & $0.4543 \pm 0.0025$ & -545.7 & 129416 \\
\hline
\end{tabular}

